\title{
How Mechanical Forces Change the Human Endometrium during the Menstrual Cycle in Preparation for Embryo Implantation
}

\author{
Anna K. Sternberg, Volker U. Buck, Irmgard Classen-Linke and Rudolf E. Leube *(D) \\ Institute of Molecular and Cellular Anatomy, RWTH Aachen University, Wendlingweg 2, \\ 52074 Aachen, Germany; asternberg@ukaachen.de (A.K.S.); vbuck@ukaachen.de (V.U.B.); \\ iclassen-linke@ukaachen.de (I.C.-L.) \\ * Correspondence: rleube@ukaachen.de; Tel.: +49-241-80-89107; Fax: +49-241-80-82508
}

check for

updates

Citation: Sternberg, A.K.; Buck, V.U.; Classen-Linke, I.; Leube, R.E. How Mechanical Forces Change the Human Endometrium during the Menstrual Cycle in Preparation for Embryo Implantation. Cells 2021, 10, 2008. https://doi.org/10.3390/ cells10082008

Academic Editor: Alexander E. Kalyuzhny

Received: 2 July 2021

Accepted: 3 August 2021

Published: 6 August 2021

Publisher's Note: MDPI stays neutral with regard to jurisdictional claims in published maps and institutional affiliations.

Copyright: (c) 2021 by the authors. Licensee MDPI, Basel, Switzerland. This article is an open access article distributed under the terms and conditions of the Creative Commons Attribution (CC BY) license (https:// creativecommons.org/licenses/by/ $4.0 /)$.
Abstract: The human endometrium is characterized by exceptional plasticity, as evidenced by rapid growth and differentiation during the menstrual cycle and fast tissue remodeling during early pregnancy. Past work has rarely addressed the role of cellular mechanics in these processes. It is becoming increasingly clear that sensing and responding to mechanical forces are as significant for cell behavior as biochemical signaling. Here, we provide an overview of experimental evidence and concepts that illustrate how mechanical forces influence endometrial cell behavior during the hormone-driven menstrual cycle and prepare the endometrium for embryo implantation. Given the fundamental species differences during implantation, we restrict the review to the human situation. Novel technologies and devices such as 3D multifrequency magnetic resonance elastography, atomic force microscopy, organ-on-a-chip microfluidic systems, stem-cell-derived organoid formation, and complex 3D co-culture systems have propelled the understanding how endometrial receptivity and blastocyst implantation are regulated in the human uterus. Accumulating evidence has shown that junctional adhesion, cytoskeletal rearrangement, and extracellular matrix stiffness affect the local force balance that regulates endometrial differentiation and blastocyst invasion. A focus of this review is on the hormonal regulation of endometrial epithelial cell mechanics. We discuss potential implications for embryo implantation.

Keywords: mechanobiology; endometrial epithelium; embryo; endometrial crosstalk; adhesion; cytoskeleton; mechanosensitive ion channels; extracellular matrix; trophoblast; decidua

\section{Introduction}

According to the World Health Organization, one in ten couples is dependent on assisted reproductive technology [1,2]. The causes for infertility are manifold and include insufficient sperm production, hormonal imbalances, and stress [3,4]. Aspects that have received little attention are hormone-dependent changes in the biomechanical properties of the uterine endometrium that allow it to become receptive for embryo implantation [5]. The endometrium is the innermost layer of the uterine wall (Appendix A; Figure 1). It is adjacent to the contractile myometrium and the outermost perimetrium, which abuts the pelvic connective tissue and extends into the peritoneal cavity. The endometrium consists of surface epithelium that is connected to the uterine glands, which are embedded in loose connective tissue. Major structural changes occur in the endometrium during the $\sim 28$ day menstrual cycle (Appendix A; Figures 1 and 2), whereby the upper part, i.e., the functional layer or stratum functionale of the endometrium, is completely shed during desquamation, rebuilt during the ensuing proliferative phase, and restructured during the secretory phase. Estrogen is the major stimulant during the proliferative phase, and it is coupled to glandular, connective tissue, and blood vessel growth, whereas progesterone is the major stimulant during the secretory phase. The secretory phase is characterized by 
glandular secretion coincident with altered permeability, adhesion, and surface receptor expression in the epithelial compartment, as well as with the decidualization of the connective tissue compartment. Decidualization involves drastic changes in the extracellular matrix and the partial mesenchymal-epithelial transition of resident fibroblasts, which together result in tissue softening [6]. Endometrial proliferation and differentiation prepare the uterine wall for embryo implantation. We argue that these preparatory changes alter the mechanical properties of the endometrium in such a way that they enhance the adhesion of the blastocyst and its migration through the epithelial surface layer into the underlying connective tissue compartment (Appendix A; Figure 3). Evidence for this concept is the observation that implantation is only possible during a short period of the secretory phase. This approximately two-to-four day receptive period is referred to as the window of implantation.

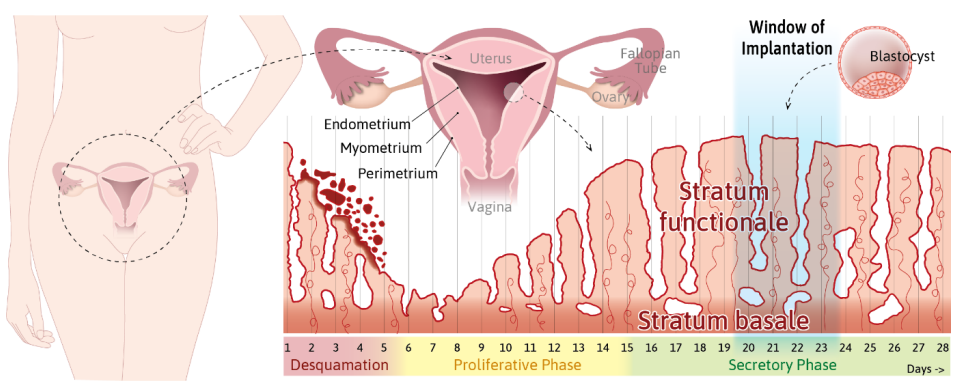

Figure 1. The plasticity and contractility of the human uterus require the constant adjustment of the endometrium to prepare and support embryo implantation and enable subsequent embryo development. The scheme highlights the multilayered wall structure of the uterus and menstrual cycle-dependent endometrial changes. The uterus is positioned in the pelvis below the peritoneal cavity. The inverted cone-shaped organ is connected through the Fallopian tube to the ovaries and opens into the vagina. It consists of three major layers: the outer connective tissue-rich perimetrium, the smooth muscle-containing contractile myometrium, and the inner endometrium. The endometrium can be further subdivided into the permanent stratum basale and the transitory stratum functionale, which is shed during desquamation and rebuilt during the proliferative phase, with changes in differentiation during the secretory phase to prepare for blastocyst implantation during the window of implantation. For further details, see Info Boxes 1 and 2 (Appendix A).

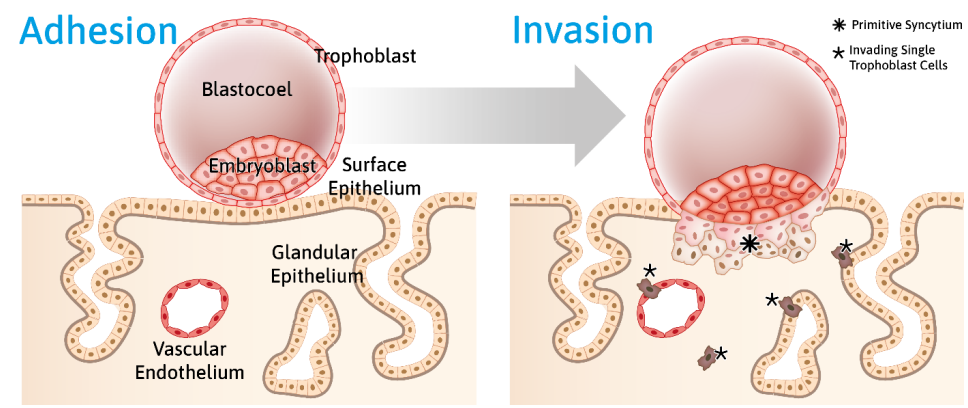

Figure 2. Schematic representation of blastocyst adhesion to the endometrial epithelium and subsequent trophoblast invasion into the endometrium. The developing blastocyst-consisting of the fluid-filled blastocoel, the embryoblast encompassing the inner cell mass, and the outer trophoblast cell layer-adheres to the uterine surface epithelium. Adhesion induces processes in both the embryonic blastocyst and the maternal epithelial and stromal cell layers, which result in the transmigration of the trophoblast through the epithelial layer and the invasion of the endometrial stromal compartment. Subsequently, specialized single trophoblast cells, the extravillous trophoblasts, invade the decidua and erode endothelia and glandular epithelia from their respective basal sides. For further details, see Info Box 3 (Appendix A). 


\section{Proliferative Phase}

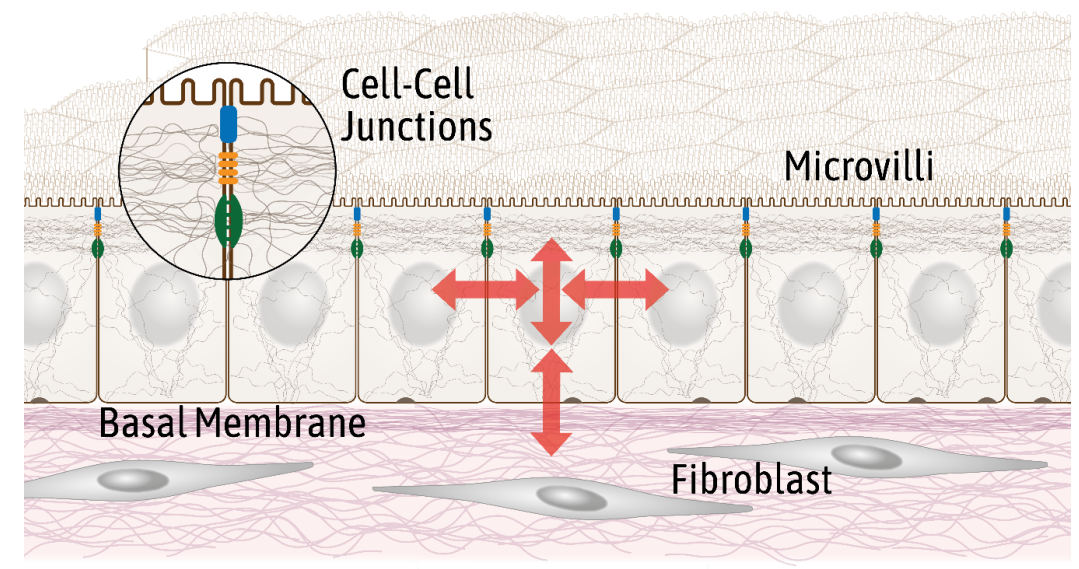

\section{Window of Implantation}

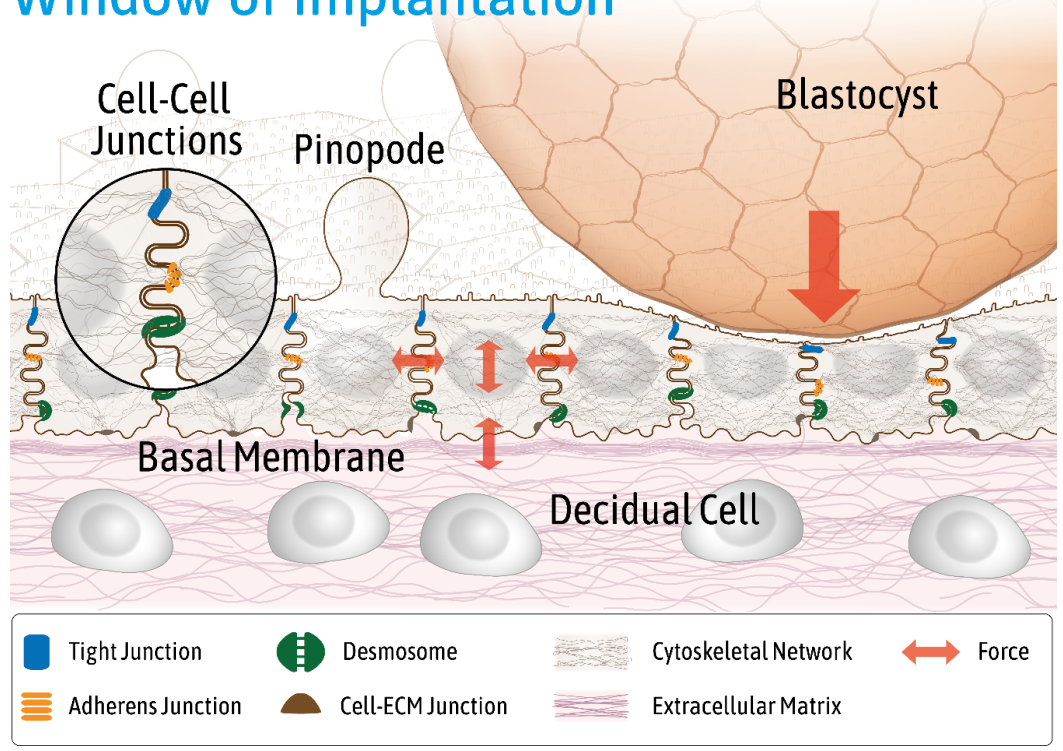

Figure 3. The schemes highlight endometrial changes affecting endometrial biomechanics during the menstrual cycle in preparation for blastocyst adhesion and invasion. Key features of the endometrium during the proliferative phase are depicted at the top, and key features during the window of implantation are depicted at the bottom. Note the differences in the endometrial epithelial cell layer including cell height, apical surface specializations (e.g., microvilli and pinopodes), cytoskeletal organization, nuclear morphology and position, distribution of lateral cell-cell junctions, and basolateral plasma membrane invaginations. Additionally note the changes in the connective tissue compartment with a reduced fiber content and altered fibroblast morphology during the window of implantation, thus providing a different biomechanical environment for the epithelial cell layer. The adhering blastocyst impacts the epithelium from the apical side. The red arrows indicate different types of forces that act in all spatial directions within and on the endometrial epithelium. They include shear stress from the uterine lumen, hydrostatic pressure from the adhering blastocyst, tensile forces within the epithelium, traction forces resulting from the epithelial-stromal interphase, and intracellular contractile forces. Epithelial viscoelasticity and extracellular matrix stiffness have impacts on force distribution. 
The preparation of the endometrial epithelium and, even more so, the attachment and invasion of the developing blastocyst require a tight and coordinated force balance between maternal and embryonic components. This view is one of the basic tenets of the expanding field of mechanobiology (Appendix A, Glossary). Mechanobiology is based on the understanding that genetic programs are modulated by mechanical stimuli of the environment. The modulatory effects are balanced by complex feedback mechanisms and result in coordinated emergent tissue behavior. They require mechanosensing and mechanotransmission through specialized molecules (such as channels and extensible polypeptide domains) and structures (adhesion sites), as well as mechanotransduction through signaling pathways involving biochemical signals to elicit cellular responses (e.g., reorganization of the cytoskeleton, contraction, and proliferation), which together lead to a new force balance. Mechanical forces thereby contribute to tissue homeostasis and are involved in development and repair. The dysfunction of these mechanisms and feedback loops results in disease and tumorigenesis.

In the following paragraphs, we highlight aspects of the mechanophysical plasticity of the human endometrium during the menstrual cycle in preparation for embryo implantation.

\section{Mechanical Properties of the Endometrium Change during the Menstrual Cycle}

To study menstrual cycle-dependent mechanical properties of the endometrium in vivo, three-dimensional multifrequency magnetic resonance elastography combined with multifrequency dual elasto-visco inversion has been used [7]. This is a novel, noninvasive approach to study the haptic material properties of tissues in vivo and allows one to measure the response of viscoelastic material to vibration, which is described as complex shear modulus $\left|G^{*}\right|$ [7]. The $\left|G^{*}\right|$ of the endometrium was found to be higher during the proliferative phase $(3.34 \pm 0.42 \mathrm{kPa})$ than during the early secretory phase $(1.97 \pm 0.34 \mathrm{kPa})$ in healthy volunteers [8]. Whether these differences reflect overall differences of the entire endometrium or differences between the functional and basal endometrial layer cannot be decided. However, we have assumed that the very loose connective tissue surrounding the extensive glands of the stratum functionale contributes to the increased softness during the secretory phase.

An important aspect of the steroid hormone-dependent mechanical properties of the endometrium are the known menstrual cycle-dependent changes in basement membrane composition and the overall changes in extracellular matrix composition. Stromal edema and reduced fibrous components are hallmark features of the connective tissue compartment during the mid secretory phase [9]. The general belief is that tissue-loosening aids implantation. An immunohistochemical study of the human endometrium revealed drastic changes in immunoreactivity for various extracellular matrix components, most notably including the basement components collagen type IV and laminin [10]. Another study [11] reported the detection of collagen type IV, fibronectin, and laminin during the secretory phase in the endometrial stroma of normal fertile women, as well as consistently reduced or absent levels of these polypeptides in women suffering from unexplained infertility. Of relevance may be the observed transient reduction of laminin and fibronectin around the window of implantation. Tanaka et al. [12] immunostained endometrial biopsies for collagen IV and laminin, and they found reduced laminin in the basement membrane of the endometrial surface epithelium and, to a lesser extent, in the basement membrane of the glandular epithelium during the secretory phase. In contrast to the other menstrual cycle phases, collagen IV was slightly decreased in the basement membrane of both luminal and glandular endometrial epithelial cells during the late proliferative phase, indicating an estrogen-dependent regulation [12]. Taken together, the reduction of the basement membrane component collagen IV (which is highly resistant to mechanical forces because of its cross-linked trimeric subunits $[13,14])$ and the reduction of laminin weaken the basement membrane of the endometrial epithelium. This may help extravillous trophoblast cells invade endometrial glands to provide histiotrophic nourishment for the embryo. 


\section{Endometrial Epithelial Cells Change Junctional Arrangement to Become Receptive}

It has been suggested that luminal and glandular endometrial epithelial cells lose polarity and convert to a more mesenchymal-like phenotype during the window of implantation $[15,16]$. This conversion is accompanied by fundamental changes of plasma membrane organization, which affects the membrane's overall structure and composition and has been referred to as plasma membrane transformation $[16,17]$. The partial epithelial-to-mesenchymal transition presumably reduces the barrier function of the endometrium for the embryo to implant. Manifestations of the structural and functional transition in the human endometrium include the downregulation of $\mathrm{N}$-cadherin [18], changes in apical marker enzyme expression $[19,20]$, the reduction of apical microvilli [21] with the development of large apical membrane protrusions referred to as pinopodes [22], increased plasma membrane tortuosity [23], cytoskeletal reorganization $[6,24,25]$, changes in cell-extracellular matrix contacts [26], and the rearrangement of the tripartite junctional complex $[27,28]$ (Figure 3).

The tripartite junctional complex consists, from apical to basal, of the circumferential tight junction, which tightly seals the intercellular space, the belt-like actin-associated adherens junction, and the spot-like keratin intermediate filament-associated desmosome. Desmosomal and adherens junction proteins are mainly localized subapically during the proliferative (days 6-14) and early-to-mid secretory phase (day 20) in endometrial epithelial cells of the stratum functionale. Both junctions become evenly distributed along the lateral plasma membrane during the window of implantation [27] (see also Figure 4). The gene expression of junctional proteins such as that of desmoplakin and E-cadherin, however, does not significantly change during the menstrual cycle [18,27]. Tight junctions remain apical [27] but develop additional strands that move further down along the lateral plasma membrane in luminal endometrial epithelial cells around the time of ovulation [29]. A potentially relevant observation in this context is that the GTPase Rab13, which has been implicated in endosomal trafficking to the lateral plasma membrane, colocalizes with the desmosomal cadherin desmoglein 2 during the window of implantation but not with the tight junction protein $\mathrm{ZO}-1$ or the adherens junction protein E-cadherin in the endometrium of rats [30]. The authors therefore proposed that Rab13 contributes to the redistribution of desmosomes. Overall, the rearrangement of the junctional complex may weaken cell-cell adhesion and prepare the endometrium for trophoblast invasion. Comparable alterations of junctional rearrangements were also observed in 3D in vitro cell models [26] (see also Figure 4). Thus, a redistribution of desmosomes and adherens junctions was documented in response to estrogen, progesterone, and a combination of both in 3D acini prepared from the moderately polarized endometrial epithelial cell line Ishikawa [26].

Changes in cell-extracellular matrix contacts are also observed as intercellular spaces widen and extracellular matrix components intercalate between basolateral intercellular spaces. An indication of this re-organization and altered mechanical interface is the reported menstrual cycle-dependent redistribution of the hemidesmosomal $\alpha 6 / \beta 4$-integrin, which serves as a laminin-332 receptor. The lateralization of the a6-integrin subunit has been observed in vivo in a receptive endometrium and in vitro in endometrial epithelial cell-derived 3D acini upon hormone stimulation [26,32]. In addition, significant alterations in the expression pattern of $\alpha 1 \beta 1, \alpha 4 \beta 1, \alpha v \beta 3$, and $\alpha 6 \beta 1$ integrins have been detected during the menstrual cycle and, more specifically, during the window of implantation in the endometrial epithelium [32,33].

Together, the findings indicate that the hormone-dependent changes in endometrial epithelial cells reflect a transition between two physical states that have been referred to as jamming and unjamming (see, e.g., $[34,35]$ ). Unjammed cells are free to move as in a fluid, whereas the movement of jammed cells is constrained as in a solid. The transition between both states depends on a variety of biophysical parameters such as intercellular adhesion, cortical tension, and 3D matrix confinement, and it is reflected by changes in cell shape. The underlying biomechanical concept is based on observations in epithelia that undergo fundamental changes in epithelial cohesiveness, tension, and stress regulating 
basic cellular properties such as migration, proliferation, and carcinogenesis (e.g., [36]). Future studies will reveal whether this concept also applies to menstrual cycle-dependent endometrial plasticity.
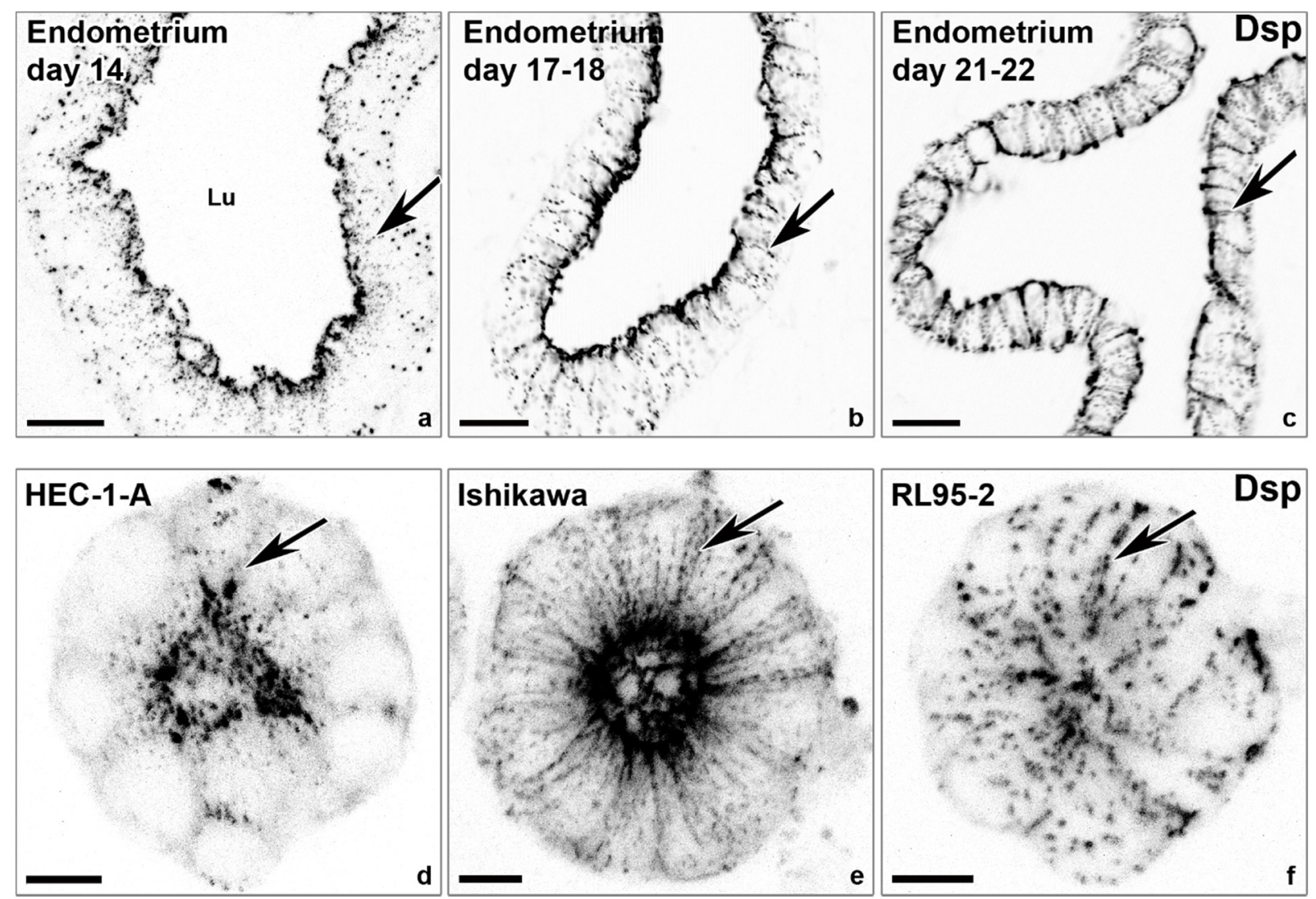

Figure 4. The lateralization of desmosomal cell-cell adhesions coincides with the window of implantation and polarization of endometrial epithelial cell lines. The confocal fluorescence micrographs (inverse presentation; single focal planes are shown in $(\mathbf{a}-\mathbf{c})$; the projections of 8 consecutive focal planes shown in $(\mathbf{d}-\mathbf{f}))$ reveal anti-desmoplakin (Dsp) reactivity that detects punctate desmosomes in the endometrial epithelial cell layer of the human endometrium obtained at different days of the menstrual cycle $(\mathbf{a}-\mathbf{c})$ and in gland-like spheroids $(\mathbf{d}-\mathbf{f})$ derived from endometrial adenocarcinoma cell lines with high polarity (HEC-1-A), intermediate polarity (Ishikawa), and low polarity (RL95-2). Note the different distributions of desmoplakin-positive desmosomes along the basolateral plasma membrane (arrows). Lu, lumen. Scale bars: $20 \mu \mathrm{m}$ (a-c), $10 \mu \mathrm{m}(\mathbf{d}-\mathbf{f})$. The images were modified from $[27,31]$.

\section{Hormone-Dependent Cytoskeletal Rearrangements Regulate Trophoblast Adhesion}

It has been suggested that cytoskeletal rearrangements alter epithelial cell stability during the menstrual cycle [37-41]. In accordance, the inhibition of actin polymerization by cytochalasin D in the endometrial epithelial cell line RL95-2, which is commonly used as a model of a receptive endometrium [42,43], was found to reduce trophoblast-adhesiveness at the apical endometrial cell pole [24]. The researchers speculated that the treatment led to the dissociation of integrins and the actin cytoskeleton and that, conversely, an intact integrin-actin system is needed for trophoblast adhesion in non-polar RL95-2 cells.

Even less is known about menstrual cycle-dependent changes in the organization of the cytoplasmic intermediate filament cytoskeleton of endometrial epithelial cells. However, the observed alterations in desmosome distribution and the actin system [24,26,27], which are known to act in concert, indicate that the 3D organization of the intermediate filament cytoskeleton is also modulated during the menstrual cycle. Following other polarized epithelia [44-47], we expect that the keratin network is apically concentrated below the actin-rich terminal web in a non-receptive endometrium and propose that this distribution switches to a non-polarized, pancytoplasmic distribution during the window 
of implantation. In addition to the structural re-organization of intermediate filament cytoskeleton, compositional alterations also occur. As such, keratin 13 was shown to be exclusively expressed in the surface epithelium during the proliferative phase and was not detected in a secretory-phase uterine epithelium [25]. Similarly, keratin 86 was found to be upregulated in a murine endometrium during peri-implantation [48]; furthermore, keratin 86 expression was enhanced by high estrogen levels and ameliorated by progesterone.

\section{Steroid Hormones Regulate Apicobasal Organization in Endometrial Epithelial Cells}

Little is known about the activity of cellular pathways that may regulate polarity switching in the endometrial epithelium during the menstrual cycle. In polarized epithelial cells, apicobasal polarity is mainly controlled by the Crumbs, Par, and Scribble complexes, which were first described in Drosophila melanogaster [49]. Crumbs and Par specify the apical domain, and Scribble the basolateral domain. The immunostaining of the endometrium revealed that all three protein complexes are present in luminal and glandular epithelial cells, with limited localization in the stroma [50]. Steroid hormone-driven cyclic changes of these complexes in luminal endometrial epithelial cells of the stratum functionale were reported [50]. Atypical protein kinase C, which is part of the apically localized Par complex, was shown to be downregulated during the entire secretory phase [50]. It was further observed that Crumbs and the Crumbs-associated protein Stardust were downregulated during the late secretory phase [50]. These findings indicate a loss of apical polarity during the secretory phase and, especially, during the window of implantation, and they suggest that this may be regulated by the Par and the Crumbs complexes under the control of estrogen and progesterone.

The basolateral determinant Scribble is also downregulated in luminal endometrial epithelial cells during mid and late secretory phase, but it is upregulated in stromal cells during the late secretory phase and could therefore play a role in decidualization [50]. The hormone-dependent regulation of Scribble was also reported in the endometrial cancer cell line ECC-1 [50], which was later reclassified as Ishikawa [51]. A combination of estrogen, progestin, and the trophoblast-derived hormone human choriogonadotropin (hCG) induced the downregulation of Scribble. Furthermore, the experimental downregulation of Scribble by siRNA increased trophoblast adhesion and improved decidualization efficiency [50].

In conclusion, it appears that apical polarity is controlled by maternal steroid hormones, whereas basolateral identity is affected by embryonic trophoblast-derived signals such as hCG.

\section{Mechanical Stimuli Enhance Decidualization of Endometrial Stromal Cells}

As discussed, luminal endometrial epithelial cells loosen their cell-cell adhesion, reorganize their cytoskeleton, and shift their morphology towards a mesenchymal phenotype during the secretory phase of the menstrual cycle in order to become receptive for embryo implantation by resembling partial epithelial-to-mesenchymal transition [15,50]. In contrast, the endometrial stromal cells undergo a progesterone-dependent mesenchymalepithelial transition during decidualization [52,53]. Around menstrual cycle days 24-28, endometrial stromal cells differentiate from a fibroblastic to an epithelioid-like state [54]. Interestingly, the origin of this differentiation process is closely localized to the terminal spiral arterioles [9]. Using a novel organ-on-a-chip microfluidic system, it was shown that laminar shear stress enhances the decidualization of primary endometrium-derived stromal fibroblasts when co-cultured with endothelial cells [55]. This observation supports the idea that mechanical stimuli imposed by the increased blood flow of the differentiated endometrium contribute to the regulation of human decidualization. The colloidal probe nanoindentation of endometrial stromal cells detected cell softening during in vitro decidualization, which may be caused by cytoskeletal reorganization, specifically by the downregulation of vimentin, upregulation of keratins, and destabilization of F-actin $[6,56]$. 
Conversely, increased matrix stiffness was found to induce F-actin fiber formation and proliferation of endometrial stromal cells in vitro [57].

\section{Mechanical Cues Modulate Embryo-Endometrial Interaction}

To study the adhesion forces between trophoblast cells and endometrial epithelial cells, in vitro experiments were performed using human cell lines. Endometrial epithelial cell lines with either a high degree of polarization (HEC-1-A) or a low degree of polarization (RL95-2) were used to mimic non-receptive and receptive endometria, respectively [42,58-61]. They were combined with the human choriocarcinoma-derived trophoblast-type cell line JAR [62]. Time-dependent adhesion was measured with the help of an atomic force microscopy tip that was functionalized with JAR cells and brought into contact with HEC-1-A and RL95-2. After contact times of 20-40 min with a JAR-coated cantilever, the polarized HEC-1-A cells showed an adhesive force maximum of $16 \pm 4 \mathrm{nN}$ and a relatively smooth cell surface separation at a distance of 8-20 $\mu \mathrm{m}$. On the other hand, the less polarized RL95-2 cells did not separate from JAR cells but ruptured at forces of $15 \pm 4 \mathrm{nN}$ at a distance of about $45 \mu \mathrm{m}$, indicating that cell-cell adhesion proteins were mechanically destroyed by the pulling [63]. In contrast to HEC-1-A, the apical plasma membrane of RL95-2 lacks microvilli [59] and has a thinner glycocalyx [61], thus enabling easier accessibility for trophoblast adhesion.

Interestingly, firm adhesion between JAR and RL95-2 was only observed when the JAR-functionalized tip indented the apical surface of the RL95-2 cells [63]. This further highlights the idea that implantation is dependent on mechanical cues. In vivo support for this idea was revealed in a study showing that mammalian blastocysts undergo swelling during apposition just before implantation [64]. Thus, the hydrostatic pressure exerted by the embryo might play a role in causing the endometrium to become more receptive.

\section{Trophoblast Penetration of the Epithelial Barrier Is a Multimodal Process}

The penetration of endometrial epithelial cells by the embryonic trophoblast has not been observed in humans, and practically no histological data regarding the very initial stages of this process are available (regarding later stages, see, e.g., $[65,66])$. It is known, however, that the trophoblast can penetrate the epithelial barrier from both the apical side, which occurs after attachment to the apical side of the endometrial surface epithelium, and the basal side, which occurs during the erosion of the glandular epithelium after trophoblast invasion. Both processes may involve a combination of protease-mediated channeling and active movement that involves the contractile acto-myosin system. Furthermore, it is generally accepted that trophoblast cells migrate as both single cells (i.e., single extravillous trophoblast cells in the decidua) and cell collectives (i.e., villous trophoblast cells). It remains to be worked out, however, whether trophoblasts move transcellularly or through the weakened paracellular spaces of the endometrial epithelium, as well as which mechanophysical mechanisms guide the transepithelial migration of the trophoblast. Complex co-culture systems are being established to investigate mechanistic and molecular details of trophoblast migration cells across the endometrial epithelial cell layer. Our own attempts using human endometrial epithelial-cell-line-derived gland-like acini and human trophoblast cells have been encouraging, because they have revealed an inverse correlation between the degree of endometrial epithelial polarization and trophoblast invasion [31].

\section{Invading Extravillous Trophoblast Cells Increase Decidual Stiffness by Remodeling Vasculature and Extracellular Matrix}

The uterus remodels to provide an optimal embryonic environment during gestation, especially regarding placentation, i.e., the development of the placenta. The placenta develops from the trophectoderm of the blastocyst during the first trimester of pregnancy. Highly invasive trophoblast cells form cell columns at the tips of anchoring villi, from which single extravillous trophoblast cells migrate into the decidua basalis. The invading trophoblast cells enter and remodel maternal spiral arteries and endometrial glands to ensure embryonic nutrition (Figure 2) [67-69]. 
To feed and support the developing embryo, the uterine blood supply is enhanced. Remarkably, maternal uterine blood flow increases manyfold during pregnancy [70]. In the non-pregnant state, uterine artery blood flow ranges from $22.4 \pm 7.3 \mathrm{~mL} / \mathrm{min}$ during the proliferative phase to $30.7 \pm 13.7 \mathrm{~mL} / \mathrm{min}$ in the secretory phase [71], whereas blood flow in the late phase of pregnancy reaches up to $750 \mathrm{~mL} / \mathrm{min}$ [70]. It is safe to assume that the shear stress of the uterine arteries rises with the increase in blood volume. Arteries undergo extensive dilation, and spiral arteries are actively remodeled by extravillous trophoblast cells, changing not only their morphology and structure but also their mechanical properties. An ex vivo study performed by Abbas et al. in 2019 [72] measured the stiffness of the decidua basalis, decidua parietalis, and placenta at a gestational age of between 8 and 10 weeks by atomic force microscopy; they revealed that the decidua basalis with placental villi was significantly stiffer than the non-invaded decidua parietalis and placenta [72] Hence, invading extravillous trophoblast cells mainly contribute to or induce endometrial stiffness. The remodeling of spiral arteries results in the replacement of the musculoelastic wall by a fibrinoid material that embeds intramural extravillous trophoblast cells [73]. Large areas within the invaded decidua become necrotic and accumulate fibrinoid material in Nitabuch's layer, presumably increasing local tissue stiffness [74].

A second factor contributing to enhanced endometrial stiffness during embryo implantation and development is the remodeling of the extracellular matrix when invading trophoblast cells secrete extracellular matrix proteins and matrix metalloproteases. Trophoblast cells predominantly produce laminin, fibronectin, collagen IV, and fibrillin I $[72,75,76]$. Decidual cells also produce laminin and collagen IV [77]. Though laminin is the main extracellular matrix component of the villous trophoblast basement membrane, single extravillous trophoblast cells predominantly produce fibronectin [75]. Fibronectin is quite soft and assembles into highly extensible fibers when stress is applied [78]. Though fibronectin may be a key player in extravillous trophoblast migration [79], it is unlikely to be associated with decidua stiffening. Interestingly, collagen IV expression is significantly upregulated in the stroma of an invaded decidua basalis compared to a decidua parietalis, especially around invading extravillous trophoblast cells [76]. Due to collagen IV's nonfibrillar nature, it is not directly associated with tissue stiffness; rather, it is associated with enhanced stress resistance [14]. The glycoprotein fibrillin I, on the other hand, arranges in microfibril networks that act as stiff polymers with a Young's modulus between 78 and $96 \mathrm{MPa}$ [80]. In 2019, Abbas et al. [72] hypothesized that a specific combination of fibrillin I-rich extracellular matrix proteins produced by extravillous trophoblast cells induces the stiffening of the decidua basalis while degrading stromal extracellular matrix proteins with serine proteases and matrix metalloproteases (see also [81,82]).

Conversely, connective tissue stiffness influences the morphology and invasion potential of extravillous trophoblast cells [83], which may serve as a negative feedback loop. When the extravillous trophoblast cells reach the myometrium, which is considerably stiffer than the decidua, they stop migrating altogether and fuse into multinucleated giant cells [84]. The function of these giant cells is not well understood, but they secrete collagenases and matrix metalloproteases, which may soften the maternal tissue [85].

\section{Superficial Endometrial Injuries May Improve Embryo Implantation Rates}

The mechanical injury of the endometrium by a uterine scratch biopsy during the early-to-mid secretory phase can improve implantation and birth rates in patients with recurrent implantation failure $([86,87]$. Contrasting results $[88,89]$ may be explained by differences in study design, selection of patients, patient age, or the number of biopsies performed. A recent systematic review and meta-analysis [90] of ten selected studies with 1260 patients revealed overall higher clinical pregnancy and live birth rates in the endometrial injury group.

Decidualization in rodents, which is normally triggered by the embryo, can be artificially and fully induced in pseudopregnant or hormonally-prepared animals with diverse mechanical stimuli such as oil injection [91]. Mechanical manipulation is linked to decidual 
cell growth, which is triggered by cytokine and growth factor secretion. Furthermore, microarray assays determined that genes that are known to be involved in the implantation process, including transmembrane protein mucin 1, phospholipase $\mathrm{A} 2$, and uroplakin $\mathrm{Ib}$, are upregulated after uterine injury [92]. The cytokine prostaglandin E2 may play a major role in scratch-induced endometrial alterations because it is a known regulator of decidualization $[93,94]$. Interestingly, the epithelial mechanosensitive sodium channel (ENaC), which is synthesized in endometrial epithelial cells, regulates prostaglandin E2 production [95-98]. It was therefore hypothesized that $\mathrm{ENaC}$ is a key transducer for improved implantation rates after taking endometrial scratch biopsies [99]. This is supported by the detection of lower levels of endometrial $\mathrm{ENaC} \alpha$ subunit expression in patients undergoing in vitro fertilization with failed pregnancy [98].

\section{ENaC, Piezo1 and TRP Are Functionally Expressed in Endometrial Epithelial Cells and May Contribute to Embryo-Endometrial Epithelial Cell Crosstalk}

It has been demonstrated by whole-cell patch-clamp experiments of human endometrial biopsies that the application of a mechanical stimulus (i.e., indentation) results in an increase in current density. This effect was fully inhibited by GsMTx4, an inhibitor of mechanosensitive ion channels [100,101]. Thus far, besides ENaC, Piezo1 and members of the transient receptor potential (TRP) superfamily have been described in the endometrium $[97,101,102]$.

$\mathrm{ENaC}$ is located on the apical plasma membrane of human luminal endometrial epithelial cells [97]. When stimulated with the protease activator trypsin, a calcium influx in human endometrial epithelial cells has been observed [101,103], indicating the functional expression of this ion channel. As discussed above, ENaC may play a crucial role in responding to mechanical stimuli and may therefore be a critical protein in embryo-endometrium interaction during implantation.

Piezo1 is a mechanically-activated ion channel that is known to affect cytoskeletal organization and function (review in [104]). Piezo1 was found to be functionally present in human EEC at different stages of the menstrual cycle [101]. The expression of Piezo1 but not Piezo2 was detected by RT-qPCR in human endometrial epithelial and stromal cells [101]. The mechanosensitivity of endometrial epithelial cells was shown by mechanically stimulating the cell membrane, which resulted in a robust calcium influx that could be intensified by the Piezo1 agonist Yoda1 [105].

It may be relevant for understanding the role of $\mathrm{ENaC}$ and piezo in embryo-endometrial crosstalk that they are themselves regulated by submembranous actin dynamics (review in [106]), which may be part of a regulatory feedback loop. The relevance of this fact is emphasized by the observation that reduced actin polymerization has been identified as a potential mechanism of viral-induced implantation failure [107].

Several members of the classical (C) and vanilloid (V) TRP family, which are produced in various vertebrate tissues, have been found to be activated by mechanical stimuli such as stretching (TRPV2, TRPV4, and TRPC1) or shear stress (TRPV4) (as reviewed in $[108,109]$ ). In non-pregnant endometrial biopsies, these and other members of the TRP channel protein family could be detected by qRT-PCR [101,102]. The expression levels of TRPV2, TRPV4, and TRPC1 vary during the menstrual cycle: TRPV2 is upregulated during the late secretory phase and menstruation, TRPV4 is downregulated during the entire secretory phase, and TRPC1 is downregulated during menstruation but does not show different expression levels during the proliferative and secretory phases [102]. These findings stress that TRP expression in the uterus is regulated by steroid hormones, as has been shown for progesterone-responsive TRPC5 [110] and estrogen-responsive TRPV6 [111]. Remarkably, these changes in functional relevance occur during the window of implantation [102], potentially responding to the physical forces that the embryo exerts toward the luminal endometrial epithelium and may therefore be critical for embryo invasion. However, the functional expression of TRPV2, TRPV4, and TRPC1 could not be detected in human endometrial epithelial cells by measuring cellular calcium influx when stimulated with 
an agonist [101]. Thus, the role of TRP proteins in the endometrium and during embryo implantation is still unclear.

\section{TAZ Protein Is Downregulated in Endometrial Stromal Cells during Decidualization}

Intracellularly, the conversion of mechanical forces into biochemical signals takes place through the activation of several pathways. One of the most prominent pathways of mechanotransduction is the Hippo pathway and its downstream effectors YAP (Yesassociated protein) and TAZ (transcriptional coactivator with PDZ-binding motif), as reviewed in [112-114]. The immunostaining of the human uterine endometrium revealed specific YAP and TAZ reactivity in epithelial and stromal cells $[115,116]$. Additionally, YAP and TAZ could be detected by immunoblotting and immunohistochemistry in the endometrial cell line Ishikawa (erroneously referred to as ECC-1 in some publications) and in human stromal fibroblasts [117]. The TAZ protein is downregulated in endometrial stromal cells during the secretory phase. In glandular and luminal endometrial epithelial cells, there are no differences in TAZ expression patterns between the secretory and proliferative phases. During in vitro decidualization, which was induced by combined interleukin 1 beta and steroid hormone stimulation, TAZ protein levels but not mRNA levels were downregulated in stromal fibroblast cells that were obtained from human endometrial tissue [117]. Finally, the reported increased YAP protein levels in decidual endometrial stromal cells during early pregnancy [118] can be taken as a hint that the invading embryo regulates uterine Hippo pathway.

\section{The Endometrium Stiffens during Pregnancy}

Standardized methods to measure the mechanical properties of the human reproductive female tract in vivo are virtually non-existent [119]. Information on uterine mechanics is therefore scarce and has mostly been limited to analyses of the myometrium. Ex vivo studies have shown that a non-pregnant, non-contracting myometrium has non-linear material properties and is stiffer under tension than under compression $[120,121]$. The material behavior is not influenced by the menstrual cycle phase or age of the patient [120]. More recent aspiration and compression tests of entire human uteri confirmed their anisotropic and viscoelastic properties [122-124].

Only as recently as 2019, Abbas et al. [72] were the first to investigate the tissue stiffness of a human endometrium in the non-pregnant secretory phase in comparison to first trimester decidua and placenta. Using atomic force microscopy, they measured an apparent elastic modulus of $250 \mathrm{~Pa}$ in ex vivo endometrial tissue samples from nonpregnant women, whereas the elastic modulus of ex vivo tissue samples from the decidua basalis, i.e., the endometrial site of placental invasion, was determined to be $1000 \mathrm{~Pa}$ [72].

\section{Conclusions}

Within the last few years, novel and exciting research approaches have emphasized that researchers studying the menstrual cycle and human implantation must consider the impact of mechanics. With novel technologies becoming available, it will be possible to investigate aspects of female reproductive tract biomechanics in humans, thus heralding an end to the difficult-to-interpret, highly variable, and small datasets of the past. They may also provide an inroad into the analysis of specimens that are confounded by pathologies, such as myoma, sarcoma, or uterine prolapse, that may affect tissue mechanics, as has been observed in endometriosis, an estrogen-dependent disorder that is characterized by the presence of endometrial tissue outside the uterus [125]. Eutopic endometrial stromal cells from healthy women are stiffer and have a lower deformation index than cells from endometriosis patients when placed inside a microchannel system [126].

To conclude, the role of mechanical forces during the menstrual cycle and the mechanical interplay of the embryo and endometrium is far from understood at the cellular and molecular levels. To uncover the molecular mechanisms that determine the mechanical cross-talk between the developing human embryo and endometrium during implanta- 
tion, in vitro systems must be further developed (see the recent review in [127]). These approaches may involve novel 3D co-culture systems (e.g., [128]) and hormone-sensitive endometrial organoids (e.g., [129-131]; see recent reviews in [132,133]).

Author Contributions: A.K.S., I.C.-L. and R.E.L. wrote the manuscript. V.U.B. provided experimental data and supervised the project. All authors have read and agreed to the published version of the manuscript.

Funding: The research was supported by the German Research Council (346386149 (V.U.B.)) and $363055819 /$ GRK2415 (R.E.L.)), as well as the "START Program" within the Faculty of Medicine at the Rheinisch-Westfälische Technische Hochschule Aachen University (125/18, V.U.B.).

Institutional Review Board Statement: Not applicable.

Informed Consent Statement: Not applicable.

Data Availability Statement: Not applicable.

Acknowledgments: We thank Adam Breitscheidel for his excellent artwork.

Conflicts of Interest: The authors declare no conflict of interest.

\section{Glossary}

Atomic force microscopy (AFM)

Biomechanics

Complex shear modulus $\left|G^{*}\right|$

Compression

Elasticity

Mechanical force

Mechanobiology

Mechanosensing

Mechanosensitivity

Mechanotransduction

Mechanotransmission

Nanoindentation

Shear stress " $\tau$ "

Stiffness

Strain " $\varepsilon$ "
Method used in mechanobiology to quantify and apply mechanical forces in biological systems and biomaterials. The tip of a cantilever is used to probe and indent the underlying surface.

Approach to describe the structural properties of cells, tissues, organs and organisms by mechanical concepts of engineering sciences.

Response of viscoelastic material to vibration, expressed in $\mathrm{Pa}\left(=\mathrm{N} / \mathrm{m}^{2}\right)$.

Application of a mechanical force that results in a contraction of the material.

Ability of a material to resume its normal shape after being stretched or compressed. It can be quantified, for example, by Young's modulus "E".

A force that involves contact with another object and that produces a change in state of rest or motion. Mechanical forces are expressed in Newton $\left(\mathrm{N}=\mathrm{kg} \mathrm{m} / \mathrm{sec}^{2}\right)$.

Interdisciplinary field that studies the effects of mechanical forces on the physiology and pathology of living systems.

Ability of cells to sense and respond to mechanical stimuli. Quantifiable ability of a cell to sense and respond to a specific mechanical stimulus.

The molecular conversion of a mechanical signal into a biological cell response.

The transmission of an applied mechanical load to specialized structures.

Technique to measure the hardness of a material by pressing a probe against a sample.

Stress that is applied parallel or tangential to the surface of a material.

Technical term to describe the elastic properties of a material. It can be quantified by Young's modulus " $E$ ". Measure of material deformation as a result of tension or compression expressed in percentage. 
Stress

Tension

Young's modulus "E"

Viscoelasticity
Force per unit area within materials that arises from externally applied forces. It is measured in Pascal $\left(\mathrm{Pa}=\mathrm{N} / \mathrm{m}^{2}\right)$.

The application of a pulling force that results in an elongation of the material.

Stiffness value expressed in $\mathrm{Pa}\left(=\mathrm{N} / \mathrm{m}^{2}\right)$. It describes the elastic properties of a solid undergoing tension or compression in only one direction $(E=\sigma / \varepsilon)$.

Property of materials that display a mixture of viscous and elastic behavior when stressed.

\section{Appendix A}

\section{Info Box 1-The Uterine Wall (See Also Figure 1)}

The uterine wall is composed of three main layers; from outside to inside, they are: $(i)$ the loose connective tissue-containing perimetrium, which is covered by mesothelium towards the abdominal cavity, (ii) the smooth muscle cell-containing contractile myometrium, and (iii) the composite and highly variable endometrium. The endometrium consists of an epithelial compartment and a connective tissue compartment. The simple epithelium lines the endometrial surface and is contiguous with the tubular uterine glands. The connective tissue consists of stromal fibroblasts, blood vessels, and a variable number of immune cells. During the estrogen-driven proliferative phase of the menstrual cycle (days 6-14), uterine glands and the surrounding stroma enlarge to build up the stratum functionale. With ovulation and the subsequent rise in progesterone, endometrial growth comes to a halt and the endometrium prepares for nidation during the secretory phase (days 15-28). The secretory phase encompasses the differentiation of the endometrial epithelium, the secretion of uterine glands, and the decidual reaction, i.e., mesenchymal-to-epithelial transition of stromal fibroblasts, vascular remodeling, and an increase in leukocytes. Embryo implantation typically occurs midway through the secretory phase. If implantation does not take place, the stratum functionale is shed during menstruation (desquamation; days 1-5), leaving behind a residual endometrium only consisting of a remnant stratum basale, which then enters another hormone-instructed menstrual cycle.

\section{Info Box 2-The Endometrial Epithelium and Underlying Connective Tissue (See Also} Figure 3)

The endometrial epithelium is a typical polarized epithelium. The apical surface is directed towards the air/liquid-filled uterine lumen and contains microvilli and cilia. It is separated from the basolateral surface by a junctional complex consisting of the polaritymaintaining zonula occludens (tight junction), the actin filament-linked zonula adherens (adherens junction), and the keratin intermediate filament-linked macula adherens (desmosome) from top to bottom. The epithelial cells are anchored to the underlying basement membrane. The epithelial cells become receptive for implantation during the secretory phase. The cell shape changes from columnar to cuboidal; pinopodes, i.e., specialized protrusions, appear at the cell surface; and apical markers are lost. Furthermore, the glandular epithelial cells develop glycogen vacuoles and increase their secretion.

The apolar stromal cells underneath the endometrial epithelium are embedded in the extracellular matrix. They have migratory and invasive characteristics. During the secretory phase, they pre-decidualize by increasing their cytoplasmic volume and increasing the extracellular matrix volume. In the absence of a conceptus, falling progesterone levels lead to tissue breakdown catalyzed by leukocytes, which secrete matrix metalloproteases. The myometrial contractions and vasoconstriction of spiral arteries then lead to a cleavage between the stratum basale and stratum functionale.

\section{Info Box 3-Human Embryo Implantation (See Also Figure 2)}

After fertilization, the embryo moves from the Fallopian tube to the uterus, reaching it around days four-to-five as a blastocyst. The blastocyst is a fluid-filled sphere that is made 
up of 200-300 cells. It consists of an outer trophoblast cell layer that gives rise to the placenta and an inner cell mass (embryoblast) that develops into the embryo. The endometrium presents an efficient barrier that can only be penetrated by the embryo during a limited period of the menstrual cycle, i.e., during the window of implantation (days 19-23; [134]). During the window of implantation, endometrial epithelial cells rearrange their junctions through the lateralization of desmosomes and adherens junctions. Implantation starts after the hatching of the blastocyst from the surrounding zona pellucida with apposition of the trophoblast to the luminal endometrial epithelial cells. The binding of trophoblast adhesion molecules to endometrial epithelial cell ligands results in the attachment of the blastocyst. The interaction of trophoblast L-selectin with oligosaccharides of endometrial epithelial cell pinopodes initiates adhesion and integrins, and cadherins are also likely involved $[135,136]$. The modes of trophoblast migration through the epithelial cell layer are not known. As the final step of implantation, trophoblast cells invade the decidual stroma to form the placenta, which provides nourishment for the embryo. Placental villi are formed, and the maternal stroma is remodeled by various matrix metalloproteases, serine proteases, and collagenases. Extravillous trophoblast cells migrate through the stroma and invade glands and spiral arteries, resulting in histiotrophic and hemotrophic nutrition of the embryo $[68,69,137]$.

\section{Info Box 4-Mechanobiology in Health and Disease}

Mechanobiology is a highly interdisciplinary field that studies the effects of mechanical forces on the physiology and pathology of living systems. These mechanical forces include tension, compression, and shear flow, and they are modulated by cellular viscoelasticity and matrix rigidity (stiffness). Young's modulus " $\mathrm{E}$ " provides a quantitative measure for these material properties. Cells perceive and respond to mechanical forces and extracellular matrix stiffness in a process referred to as mechanosensing. Mechanotransmission is defined as the transmission of an applied mechanical load to specialized structures. They include cell-extracellular matrix contacts $[138,139]$ and, in closely spaced cells such as epithelial cells, cell-cell junctions [140]. Internal forces exerted by the cytoskeleton are also important, notably during cell migration. Mechanotransduction describes the cellular mechanism by which cells translate mechanical stimuli into biochemical signals, which elicit responses regulating, e.g., differentiation, proliferation, and apoptosis [141-143]. Healthy cells and tissues present viscoelastic behavior when stressed [144]. These responses are important for proper development and wound healing. Excessive mechanical stimulation, however, can result in pathologies, and many diseases are associated with alterations in cell stiffness. For instance, cancer cells are softer and have lower viscoelastic parameters than healthy cells [145]. Conversely, fibrosis is associated with increased tissue stiffness [146,147].

\section{References}

1. Cui, W. Mother or nothing: The agony of infertility. World Health Organ. Bull. World Health Organ. 2010, 88, 881. [CrossRef]

2. Mascarenhas, M.N.; Flaxman, S.R.; Boerma, T.; Vanderpoel, S.; Stevens, G.A. National, regional, and global trends in infertility prevalence since 1990: A systematic analysis of 277 health surveys. PLoS Med. 2012, 9, e1001356. [CrossRef]

3. Barbieri, R.L. Female infertility. In Yen and Jaffe's Reproductive Endocrinology; Elsevier: Amsterdam, The Netherlands, 2019; pp. 556-581.e557.

4. De Kretser, D.M. Male infertility. Lancet 1997, 349, 787-790. [CrossRef]

5. Evans, J.P.; Leppert, P.C. "Feeling the force" in reproduction: Mechanotransduction in reproductive processes. Connect. Tissue Res. 2016, 57, 236-244. [CrossRef] [PubMed]

6. Pan-Castillo, B.; Gazze, S.A.; Thomas, S.; Lucas, C.; Margarit, L.; Gonzalez, D.; Francis, L.W.; Conlan, R.S. Morphophysical dynamics of human endometrial cells during decidualization. Nanomedicine 2018, 14, 2235-2245. [CrossRef]

7. Muthupillai, R.; Lomas, D.; Rossman, P.; Greenleaf, J.F.; Manduca, A.; Ehman, R.L. Magnetic resonance elastography by direct visualization of propagating acoustic strain waves. Science 1995, 269, 1854-1857. [CrossRef]

8. Jiang, X.; Asbach, P.; Streitberger, K.-J.; Thomas, A.; Hamm, B.; Braun, J.; Sack, I.; Guo, J. In vivo high-resolution magnetic resonance elastography of the uterine corpus and cervix. Eur. Radiol. 2014, 24, 3025-3033. [CrossRef]

9. Noyes, R.W.; Hertig, A.T.; Rock, J. Dating the endometrial biopsy. Obstet. Gynecol. Surv. 1950, 5, 561-564. [CrossRef]

10. Aplin, J.D.; Charlton, A.K.; Ayad, S. An immunohistochemical study of human endometrial extracellular matrix during the menstrual cycle and first trimester of pregnancy. Cell Tissue Res. 1988, 253, 231-240. [CrossRef] [PubMed] 
11. Bilalis, D.; Klentzeris, L.; Fleming, S. Uterus and endometrium: Immunohistochemical localization of extracellular matrix proteins in luteal phase endometrium of fertile and infertile patients. Hum. Reprod. 1996, 11, 2713-2718. [CrossRef]

12. Tanaka, T.; Wang, C.; Umesaki, N. Remodeling of the human endometrial epithelium is regulated by laminin and type iv collagen. Int. J. Mol. Med. 2009, 23, 173-180. [CrossRef]

13. Fidler, A.L.; Vanacore, R.M.; Chetyrkin, S.V.; Pedchenko, V.K.; Bhave, G.; Yin, V.P.; Stothers, C.L.; Rose, K.L.; McDonald, W.H.; Clark, T.A.; et al. A unique covalent bond in basement membrane is a primordial innovation for tissue evolution. Proc. Natl. Acad. Sci. USA 2014, 111, 331-336. [CrossRef]

14. Vanacore, R.; Ham, A.J.; Voehler, M.; Sanders, C.R.; Conrads, T.P.; Veenstra, T.D.; Sharpless, K.B.; Dawson, P.E.; Hudson, B.G. A sulfilimine bond identified in collagen iv. Science 2009, 325, 1230-1234. [CrossRef]

15. Uchida, H.; Maruyama, T.; Masuda, H.; Uchida, S.; Miki, F.; Hihara, H.; Katakura, S.; Yoshimasa, Y.; Tanaka, M. How to create an embryo penetration route. Am. J. Reprod. Immunol. 2016, 75, 326-332. [CrossRef]

16. Whitby, S.; Zhou, W.; Dimitriadis, E. Alterations in epithelial cell polarity during endometrial receptivity: A systematic review. Front. Endocrinol. 2020, 11, 596324. [CrossRef]

17. Murphy, C.R. Uterine receptivity and the plasma membrane transformation. Cell Res. 2004, 14, 259-267. [CrossRef]

18. Tsuchiya, B.; Sato, Y.; Kameya, T.; Okayasu, I.; Mukai, K. Differential expression of n-cadherin and e-cadherin in normal human tissues. Arch. Histol. Cytol. 2006, 69, 135-145. [CrossRef]

19. Imai, K.; Maeda, M.; Fujiwara, H.; Kariya, M.; Takakura, K.; Kanzaki, H.; Mori, T. Dipeptidyl peptidase iv as a differentiation marker of the human endometrial glandular cells. Hum. Reprod. 1992, 7, 1189-1194. [CrossRef]

20. Suzuki, M.; Kuramoto, H.; Izumi, S.; Shirane, H.; Watanabe, K. Cyclic changes of alkaline phosphatase in the human endometrium: Histochemical and biochemical analyses. Acta Histochem. Cytochem. 1981, 14, 524-533. [CrossRef]

21. Martel, D.; Frydman, R.; Glissant, M.; Maggioni, C.; Roche, D.; Psychoyos, A. Scanning electron microscopy of postovulatory human endometrium in spontaneous cycles and cycles stimulated by hormone treatment. J. Endocrinol. 1987, 114, 319-324. [CrossRef]

22. Nikas, G. Pinopodes as markers of endometrial receptivity in clinical practice. Hum. Reprod. 1999, 14, 99-106. [CrossRef]

23. Gompel, C. The ultrastructure of the human endometrial cell studied by electron microscopy. Am. J. Obs. Gynecol. 1962, 84, 1000-1009. [CrossRef]

24. Thie, M.; Herter, P.; Pommerenke, H.; Dürr, F.; Sieckmann, F.; Nebe, B.; Rychly, J.; Denker, H.W. Adhesiveness of the free surface of a human endometrial monolayer for trophoblast as related to actin cytoskeleton. Mol. Hum. Reprod. 1997, 3, 275-283. [CrossRef]

25. Olson, G.E.; Winfrey, V.P.; Blaeuer, G.L.; Palisano, J.R.; NagDas, S.K. Stage-specific expression of the intermediate filament protein cytokeratin 13 in luminal epithelial cells of secretory phase human endometrium and peri-implantation stage rabbit endometrium. Biol. Reprod. 2002, 66, 1006-1015. [CrossRef]

26. Buck, V.; Kohlen, M.; Sternberg, A.; Rösing, B.; Neulen, J.; Leube, R.; Classen-Linke, I. Steroid hormones and human choriogonadotropin influence the distribution of alpha6-integrin and desmoplakin 1 in gland-like endometrial epithelial spheroids. Histochem. Cell Biol. 2021, 155, 581-591. [CrossRef]

27. Buck, V.U.; Windoffer, R.; Leube, R.E.; Classen-Linke, I. Redistribution of adhering junctions in human endometrial epithelial cells during the implantation window of the menstrual cycle. Histochem. Cell Biol. 2012, 137, 777-790. [CrossRef]

28. Murphy, C.R. Junctional barrier complexes undergo major alterations during the plasma membrane transformation of uterine epithelial cells. Hum. Reprod. 2000, 15 (Suppl. S3), 182-188. [CrossRef]

29. Murphy, C.; Swift, J.; Need, J.; Mukherjee, T.; Rogers, A. A freeze-fracture electron microscopic study of tight junctions of epithelial cells in the human uterus. Anat. Embryol. 1982, 163, 367-370. [CrossRef]

30. Lindsay, L.A.; Nasir, R.F.; Dowland, S.N.; Madawala, R.J.; Murphy, C.R. Rab13 and desmosome redistribution in uterine epithelial cells during early pregnancy. Reprod. Sci. 2021, 28, 1981-1988. [CrossRef] [PubMed]

31. Buck, V.U.; Gellersen, B.; Leube, R.E.; Classen-Linke, I. Interaction of human trophoblast cells with gland-like endometrial spheroids: A model system for trophoblast invasion. Hum. Reprod. 2015, 30, 906-916. [CrossRef]

32. Albers, A.; Thie, M.; Hohn, H.-P.; Denker, H.-W. Differential expression and localization of integrins and cd44 in the membrane domains of human uterine epithelial cells during the menstrual cycle. Cells Tissues Organs 1995, 153, 12-19. [CrossRef]

33. Lessey, B.A.; Castelbaum, A.J.; Sawin, S.W.; Buck, C.A.; Schinnar, R.; Bilker, W.; Strom, B. Aberrant integrin expression in the endometrium of women with endometriosis. J. Clin. Endocrinol. Metab. 1994, 79, 643-649.

34. Bi, D.; Yang, X.; Marchetti, M.C.; Manning, M.L. Motility-driven glass and jamming transitions in biological tissues. Phys. Rev. X 2016, 6, 021011. [CrossRef]

35. Park, J.A.; Atia, L.; Mitchel, J.A.; Fredberg, J.J.; Butler, J.P. Collective migration and cell jamming in asthma, cancer and development. J. Cell Sci. 2016, 129, 3375-3383. [CrossRef]

36. Palamidessi, A.; Malinverno, C.; Frittoli, E.; Corallino, S.; Barbieri, E.; Sigismund, S.; Beznoussenko, G.V.; Martini, E.; Garre, M.; Ferrara, I.; et al. Unjamming overcomes kinetic and proliferation arrest in terminally differentiated cells and promotes collective motility of carcinoma. Nat. Mater. 2019, 18, 1252-1263. [CrossRef]

37. Ketene, A.N.; Roberts, P.C.; Shea, A.A.; Schmelz, E.M.; Agah, M. Actin filaments play a primary role for structural integrity and viscoelastic response in cells. Integr. Biol. 2012, 4, 540-549. [CrossRef]

38. Lim, C.T.; Zhou, E.H.; Quek, S.T. Mechanical models for living cells-A review. J. Biomech. 2006, 39, 195-216. [CrossRef] 
39. Quan, F.-S.; Kim, K.S. Medical applications of the intrinsic mechanical properties of single cells. Acta Biochim. Biophys. Sin. 2016, 48, 865-871. [CrossRef] [PubMed]

40. Suresh, S. Biomechanics and biophysics of cancer cells. Acta Biomater. 2007, 3, 413-438. [CrossRef]

41. Wang, N.; Stamenovic, D. Contribution of intermediate filaments to cell stiffness, stiffening, and growth. Am. J. Physiol. Cell Physiol. 2000, 279, C188-C194. [CrossRef]

42. Raboudi, N.; Julian, J.; Rohde, L.H.; Carson, D.D. Identification of cell-surface heparin/heparan sulfate-binding proteins of a human uterine epithelial cell line (r195). J. Biol. Chem. 1992, 267, 11930-11939. [CrossRef]

43. Hannan, N.J.; Paiva, P.; Dimitriadis, E.; Salamonsen, L.A. Models for study of human embryo implantation: Choice of cell lines? Biol. Reprod. 2010, 82, 235-245. [CrossRef]

44. Coch, R.A.; Leube, R.E. Intermediate filaments and polarization in the intestinal epithelium. Cells 2016, 5, 32. [CrossRef] [PubMed]

45. Leube, R.E.; Moch, M.; Windoffer, R. Intracellular motility of intermediate filaments. Cold Spring Harb. Perspect. Biol. 2017, 9, a021980. [CrossRef] [PubMed]

46. Iwatsuki, H.; Suda, M. Seven kinds of intermediate filament networks in the cytoplasm of polarized cells: Structure and function. Acta Histochem. Cytochem. 2010, 43, 19-31. [CrossRef]

47. Tateishi, K.; Nishida, T.; Inoue, K.; Tsukita, S. Three-dimensional organization of layered apical cytoskeletal networks associated with mouse airway tissue development. Sci. Rep. 2017, 7, 43783. [CrossRef]

48. Zhang, H.; Zhao, H.; Wang, X.; Cui, X.; Jin, L. Keratin 86 is up-regulated in the uterus during implantation, induced by oestradiol. BMC Dev. Biol. 2020, 20, 3. [CrossRef]

49. Margolis, B.; Borg, J.-P. Apicobasal polarity complexes. J. Cell Sci. 2005, 118, 5157-5159. [CrossRef]

50. Whitby, S.; Salamonsen, L.A.; Evans, J. The endometrial polarity paradox: Differential regulation of polarity within secretoryphase human endometrium. Endocrinology 2018, 159, 506-518. [CrossRef]

51. Korch, C.; Spillman, M.A.; Jackson, T.A.; Jacobsen, B.M.; Murphy, S.K.; Lessey, B.A.; Jordan, V.C.; Bradford, A.P. DNA profiling analysis of endometrial and ovarian cell lines reveals misidentification, redundancy and contamination. Gynecol. Oncol. 2012, 127, 241-248. [CrossRef]

52. Gellersen, B.; Brosens, J.J. Cyclic decidualization of the human endometrium in reproductive health and failure. Endocr. Rev. 2014, 35, 851-905. [CrossRef]

53. Zhang, X.H.; Liang, X.; Liang, X.H.; Wang, T.S.; Qi, Q.R.; Deng, W.B.; Sha, A.G.; Yang, Z.M. The mesenchymal-epithelial transition during in vitro decidualization. Reprod. Sci. 2013, 20, 354-360. [CrossRef]

54. Okada, H.; Tsuzuki, T.; Murata, H. Decidualization of the human endometrium. Reprod. Med. Biol. 2018, 17, 220-227. [CrossRef] [PubMed]

55. Gnecco, J.S.; Ding, T.; Smith, C.; Lu, J.; Bruner-Tran, K.L.; Osteen, K.G. Hemodynamic forces enhance decidualization via endothelial-derived prostaglandin e2 and prostacyclin in a microfluidic model of the human endometrium. Hum. Reprod. 2019, 34, 702-714. [CrossRef]

56. Ivaska, J.; Pallari, H.-M.; Nevo, J.; Eriksson, J.E. Novel functions of vimentin in cell adhesion, migration, and signaling. Exp. Cell Res. 2007, 313, 2050-2062. [CrossRef]

57. Matsuzaki, S.; Canis, M.; Pouly, J.L.; Darcha, C. Soft matrices inhibit cell proliferation and inactivate the fibrotic phenotype of deep endometriotic stromal cells in vitro. Hum. Reprod. 2016, 31, 541-553. [CrossRef]

58. John, N.J.; Linke, M.; Denker, H.-W. Quantitation of human choriocarcinoma spheroid attachment to uterine epithelial cell monolayers. Vitr. Cell. Dev. Biol. Anim. 1993, 29, 461-468. [CrossRef]

59. Thie, M.; Fuchs, P.; Butz, S.; Sieckmann, F.; Hoschützky, H.; Kemler, R.; Denker, H. Adhesiveness of the apical surface of uterine epithelial cells: The role of junctional complex integrity. Eur. J. Cell Biol. 1996, 70, 221-232.

60. Thie, M.; Fuchs, P.; Denker, H.W. Epithelial cell polarity and embryo implantation in mammals. Int. J. Dev. Biol. 1996, 40, 389-393.

61. Thie, M.; Denker, H. Endometrial receptivity for trophoblast attachment: Model studies using cell lines. In Microscopy of Reproduction and Development. A Dynamic Approach; Antonio Delfino Editore Srl: Roma, Italy, 1997; pp. $241-249$.

62. Pattillo, R.; Hussa, R.; Bernstein, R.; Delfs, E. The jar cell line. Continuous lines of human choriocarcinoma. In Vitro 1971, 6, 398-399.

63. Thie, M.; Röspel, R.; Dettmann, W.; Benoit, M.; Ludwig, M.; Gaub, H.E.; Denker, H.-W. Interactions between trophoblast and uterine epithelium: Monitoring of adhesive forces. Hum. Reprod. 1998, 13, 3211-3219. [CrossRef] [PubMed]

64. Enders, A. Anatomical aspects of implantation. J. Reprod. Fertil. Suppl. 1976, 25, 1-15.

65. Enders, A.C. Embryo implantation, with emphasis on the rhesus monkey and the human. Reproduccion 1981, 5, 163-167. [PubMed]

66. Hertig, A.T.; Rock, J.; Adams, E.C. A description of 34 human ova within the first 17 days of development. Am. J. Anat. 1956, 98, 435-493. [CrossRef]

67. Hustin, J.; Schaaps, J.-P. Echocardiograhic and anatomic studies of the maternotrophoblastic border during the first trimester of pregnancy. Am. J. Obstet. Gynecol. 1987, 157, 162-168. [CrossRef]

68. Moser, G.; Gauster, M.; Orendi, K.; Glasner, A.; Theuerkauf, R.; Huppertz, B. Endoglandular trophoblast, an alternative route of trophoblast invasion? Analysis with novel confrontation co-culture models. Hum. Reprod. 2010, 25, 1127-1136. [CrossRef]

69. Moser, G.; Weiss, G.; Gauster, M.; Sundl, M.; Huppertz, B. Evidence from the very beginning: Endoglandular trophoblasts penetrate and replace uterine glands in situ and in vitro. Hum. Reprod. 2015, 30, 2747-2757. [CrossRef] 
70. Assali, N.; Douglass, R.A., Jr.; Baird, W.W.; Nicholson, D.; Suyemoto, R. Measurement of uterine blood flow and uterine metabolism: Iv. Results in normal pregnancy. Am. J. Obstet. Gynecol. 1953, 66, 248-253. [CrossRef]

71. Ziegler, W.F.; Bernstein, I.; Badger, G.; Leavitt, T.; Cerrero, M.L. Regional hemodynamic adaptation during the menstrual cycle. Obstet. Gynecol. 1999, 94, 695-699.

72. Abbas, Y.; Carnicer-Lombarte, A.; Gardner, L.; Thomas, J.; Brosens, J.J.; Moffett, A.; Sharkey, A.M.; Franze, K.; Burton, G.J.; Oyen, M.L. Tissue stiffness at the human maternal-fetal interface. Hum. Reprod. 2019, 34, 1999-2008. [CrossRef]

73. Pijnenborg, R.; Vercruysse, L.; Hanssens, M. The uterine spiral arteries in human pregnancy: Facts and controversies. Placenta 2006, 27, 939-958. [CrossRef]

74. Pijnenborg, R.; Dixon, G.; Robertson, W.B.; Brosens, I. Trophoblastic invasion of human decidua from 8 to 18 weeks of pregnancy. Placenta 1980, 1, 3-19. [CrossRef]

75. Burrows, T.D.; King, A.; Loke, Y. Expression of integrins by human trophoblast and differential adhesion to laminin or fibronectin. Hum. Reprod. 1993, 8, 475-484. [CrossRef]

76. Oefner, C.M.; Sharkey, A.; Gardner, L.; Critchley, H.; Oyen, M.; Moffett, A. Collagen type iv at the fetal-maternal interface. Placenta 2015, 36, 59-68. [CrossRef]

77. Iwahashi, M.; Muragaki, Y.; Ooshima, A.; Yamoto, M.; Nakano, R. Alterations in distribution and composition of the extracellular matrix during decidualization of the human endometrium. J. Reprod. Fertil. 1996, 108, 147-155. [CrossRef]

78. Klotzsch, E.; Smith, M.L.; Kubow, K.E.; Muntwyler, S.; Little, W.C.; Beyeler, F.; Gourdon, D.; Nelson, B.J.; Vogel, V. Fibronectin forms the most extensible biological fibers displaying switchable force-exposed cryptic binding sites. Proc. Natl. Acad. Sci. USA 2009, 106, 18267. [CrossRef]

79. Miyazaki, K.; Oyanagi, J.; Hoshino, D.; Togo, S.; Kumagai, H.; Miyagi, Y. Cancer cell migration on elongate protrusions of fibroblasts in collagen matrix. Sci. Rep. 2019, 9, 292. [CrossRef]

80. Sherratt, M.J.; Baldock, C.; Louise Haston, J.; Holmes, D.F.; Jones, C.J.P.; Adrian Shuttleworth, C.; Wess, T.J.; Kielty, C.M. Fibrillin microfibrils are stiff reinforcing fibres in compliant tissues. J. Mol. Biol. 2003, 332, 183-193. [CrossRef]

81. Burrows, T.D.; King, A.; Loke, Y. Trophoblast migration during human placental implantation. Hum. Reprod. Update 1996, 2, 307-321. [CrossRef]

82. Vento-Tormo, R.; Efremova, M.; Botting, R.A.; Turco, M.Y.; Vento-Tormo, M.; Meyer, K.B.; Park, J.-E.; Stephenson, E.; Polański, K.; Goncalves, A.; et al. Single-cell reconstruction of the early maternal-fetal interface in humans. Nature 2018, 563, 347-353. [CrossRef] [PubMed]

83. Ma, Z.; Sagrillo-Fagundes, L.; Mok, S.; Vaillancourt, C.; Moraes, C. Mechanobiological regulation of placental trophoblast fusion and function through extracellular matrix rigidity. Sci. Rep. 2020, 10, 5837. [CrossRef]

84. Pijnenborg, R.; Bland, J.; Robertson, W.; Dixon, G.; Brosens, I. The pattern of interstitial trophoblasticinvasion of the myometrium in early human pregnancy. Placenta 1981, 2, 303-315. [CrossRef]

85. Boyd, J.D.; Hamilton, W.J. The giant cells of the pregnant human uterus. BJOG Int. J. Obstet. Gynaecol. 1960, 67, 208-218. [CrossRef]

86. Barash, A.; Dekel, N.; Fieldust, S.; Segal, I.; Schechtman, E.; Granot, I. Local injury to the endometrium doubles the incidence of successful pregnancies in patients undergoing in vitro fertilization. Fertil. Steril. 2003, 79, 1317-1322. [CrossRef]

87. Raziel, A.; Schachter, M.; Strassburger, D.; Bern, O.; Ron-El, R.; Friedler, S. Favorable influence of local injury to the endometrium in intracytoplasmic sperm injection patients with high-order implantation failure. Fertil. Steril. 2007, 87, 198-201. [CrossRef]

88. Eskew, A.M.; Reschke, L.D.; Woolfolk, C.; Schulte, M.B.; Boots, C.E.; Broughton, D.E.; Jimenez, P.T.; Omurtag, K.R.; Keller, S.L.; Ratts, V.S.; et al. Effect of endometrial mechanical stimulation in an unselected population undergoing in vitro fertilization: Futility analysis of a double-blind randomized controlled trial. J. Assist. Reprod. Genet. 2019, 36, 299-305. [CrossRef] [PubMed]

89. Liu, W.; Tal, R.; Chao, H.; Liu, M.; Liu, Y. Effect of local endometrial injury in proliferative vs. Luteal phase on ivf outcomes in unselected subfertile women undergoing in vitro fertilization. Reprod. Biol. Endocrinol. RBE 2017, 15, 75. [CrossRef]

90. Sar-Shalom Nahshon, C.; Sagi-Dain, L.; Wiener-Megnazi, Z.; Dirnfeld, M. The impact of intentional endometrial injury on reproductive outcomes: A systematic review and meta-analysis. Hum. Reprod. Update 2019, 25, 95-113. [CrossRef] [PubMed]

91. Finn, C.; Keen, P. The induction of deciduomata in the rat. Development 1963, 11, 673-682. [CrossRef]

92. Kalma, Y.; Granot, I.; Gnainsky, Y.; Or, Y.; Czernobilsky, B.; Dekel, N.; Barash, A. Endometrial biopsy-induced gene modulation: First evidence for the expression of bladder-transmembranal uroplakin ib in human endometrium. Fertil. Steril. 2009, 91, 1042-1049.e9. [CrossRef] [PubMed]

93. Frank, G.R.; Brar, A.K.; Cedars, M.I.; Handwerger, S. Prostaglandin e2 enhances human endometrial stromal cell differentiation. Endocrinology 1994, 134, 258-263. [CrossRef] [PubMed]

94. Abrahamsohn, P.A.; Zorn, T.M. Implantation and decidualization in rodents. J. Exp. Zool. 1993, 266, 603-628. [CrossRef] [PubMed]

95. Fronius, M.; Clauss, W.G. Mechano-sensitivity of enac: May the (shear) force be with you. Pflüg. Arch. Eur. J. Physiol. 2008, 455, 775-785. [CrossRef] [PubMed]

96. Simon, A.; Shenton, F.; Hunter, I.; Banks, R.W.; Bewick, G.S. Amiloride-sensitive channels are a major contributor to mechanotransduction in mammalian muscle spindles. J. Physiol. 2010, 588, 171-185. [CrossRef]

97. Enuka, Y.; Hanukoglu, I.; Edelheit, O.; Vaknine, H.; Hanukoglu, A. Epithelial sodium channels (enac) are uniformly distributed on motile cilia in the oviduct and the respiratory airways. Histochem. Cell Biol. 2012, 137, 339-353. [CrossRef] 
98. Ruan, Y.C.; Guo, J.H.; Liu, X.; Zhang, R.; Tsang, L.L.; Da Dong, J.; Chen, H.; Yu, M.K.; Jiang, X.; Zhang, X.H.; et al. Activation of the epithelial $\mathrm{Na}^{+}$channel triggers prostaglandin $\mathrm{E}_{2}$ release and production required for embryo implantation. Nat. Med. 2012, 18, 1112-1117. [CrossRef] [PubMed]

99. Jorge, S.; Chang, S.; Barzilai, J.J.; Leppert, P.; Segars, J.H. Mechanical signaling in reproductive tissues: Mechanisms and importance. Reprod. Sci. 2014, 21, 1093-1107. [CrossRef]

100. Bae, C.; Sachs, F.; Gottlieb, P.A. The mechanosensitive ion channel Piezo1 is inhibited by the peptide GsMT $\times 4$. Biochemistry 2011, 50, 6295-6300. [CrossRef]

101. Hennes, A.; Held, K.; Boretto, M.; De Clercq, K.; Van den Eynde, C.; Vanhie, A.; Van Ranst, N.; Benoit, M.; Luyten, C.; Peeraer, K.; et al. Functional expression of the mechanosensitive piezo1 channel in primary endometrial epithelial cells and endometrial organoids. Sci. Rep. 2019, 9, 1779. [CrossRef]

102. De Clercq, K.; Held, K.; Van Bree, R.; Meuleman, C.; Peeraer, K.; Tomassetti, C.; Voets, T.; D’Hooghe, T.; Vriens, J. Functional expression of transient receptor potential channels in human endometrial stromal cells during the luteal phase of the menstrual cycle. Hum. Reprod. 2015, 30, 1421-1436. [CrossRef]

103. Vallet, V.; Chraibi, A.; Gaeggeler, H.-P.; Horisberger, J.-D.; Rossier, B.C. An epithelial serine protease activates the amiloridesensitive sodium channel. Nature 1997, 389, 607-610. [CrossRef]

104. Nourse, J.L.; Pathak, M.M. How cells channel their stress: Interplay between piezo1 and the cytoskeleton. Semin. Cell Dev. Biol. 2017, 71, 3-12. [CrossRef]

105. Syeda, R.; Xu, J.; Dubin, A.E.; Coste, B.; Mathur, J.; Huynh, T.; Matzen, J.; Lao, J.; Tully, D.C.; Engels, I.H. Chemical activation of the mechanotransduction channel Piezo1. eLife 2015, 4, e07369. [CrossRef]

106. Morachevskaya, E.A.; Sudarikova, A.V. Actin dynamics as critical ion channel regulator: ENaC and Piezo in focus. Am. J. Physiol. Cell Physiol. 2021, 320, C696-C702. [CrossRef]

107. Montazeri, M.; Sanchez-Lopez, J.A.; Caballero, I.; Maslehat Lay, N.; Elliott, S.; Lopez-Martin, S.; Yanez-Mo, M.; Fazeli, A. Activation of toll-like receptor 3 reduces actin polymerization and adhesion molecule expression in endometrial cells, a potential mechanism for viral-induced implantation failure. Hum. Reprod. 2015, 30, 893-905. [CrossRef]

108. Barritt, G.; Rychkov, G. TRPs as mechanosensitive channels. Nat. Cell Biol. 2005, 7, 105-107. [CrossRef]

109. O'Neil, R.G.; Heller, S. The mechanosensitive nature of TRPV channels. Pflüg. Arch. 2005, 451, 193-203. [CrossRef] [PubMed]

110. Majeed, Y.; Amer, M.S.; Agarwal, A.K.; McKeown, L.; Porter, K.E.; O’Regan, D.J.; Naylor, J.; Fishwick, C.W.; Muraki, K.; Beech, D.J. Stereo-selective inhibition of transient receptor potential trpc 5 cation channels by neuroactive steroids. Br. J. Pharmacol. 2011, 162, 1509-1520. [CrossRef]

111. Yang, H.; Choi, K.C.; Hyun, S.H.; Jeung, E.B. Coexpression and estrogen-mediated regulation of TRPV6 and PMCA1 in the human endometrium during the menstrual cycle. Mol. Reprod. Dev. 2011, 78, 274-282. [CrossRef]

112. Dupont, S.; Morsut, L.; Aragona, M.; Enzo, E.; Giulitti, S.; Cordenonsi, M.; Zanconato, F.; Le Digabel, J.; Forcato, M.; Bicciato, S. Role of YAP/TAZ in mechanotransduction. Nature 2011, 474, 179-183. [CrossRef] [PubMed]

113. Ma, S.; Meng, Z.; Chen, R.; Guan, K.-L. The hippo pathway: Biology and pathophysiology. Annu. Rev. Biochem. 2019, 88, 577-604. [CrossRef]

114. Zhao, B.; Wei, X.; Li, W.; Udan, R.S.; Yang, Q.; Kim, J.; Xie, J.; Ikenoue, T.; Yu, J.; Li, L. Inactivation of yap oncoprotein by the hippo pathway is involved in cell contact inhibition and tissue growth control. Genes Dev. 2007, 21, 2747-2761. [CrossRef] [PubMed]

115. Song, Y.; Fu, J.; Zhou, M.; Xiao, L.; Feng, X.; Chen, H.; Huang, W. Activated hippo/yes-associated protein pathway promotes cell proliferation and anti-apoptosis in endometrial stromal cells of endometriosis. J. Clin. Endocrinol. Metab. 2016, 101, 1552-1561. [CrossRef]

116. Strakova, Z.; Kruss, S.; Morris, K.; Reed, J. Members of the Hippo Pathway are Regulated in the Uterus during the Menstrual Cycle; Oxford University Press: Oxford, UK, 2010.

117. Strakova, Z.; Reed, J.; Ihnatovych, I. Human transcriptional coactivator with PDZ-binding motif (TAZ) is downregulated during decidualization. Biol. Reprod. 2010, 82, 1112-1118. [CrossRef]

118. Chen, H.; Song, Y.; Yang, S.; Fu, J.; Feng, X.; Huang, W. Yap mediates human decidualization of the uterine endometrial stromal cells. Placenta 2017, 53, 30-35. [CrossRef]

119. Baah-Dwomoh, A.; McGuire, J.; Tan, T.; De Vita, R. Mechanical properties of female reproductive organs and supporting connective tissues: A review of the current state of knowledge. Appl. Mech. Rev. 2016, 68, 060801. [CrossRef]

120. Conrad, J.T.; Johnson, W.L.; Kuhn, W.K.; Hunter, C.A., Jr. Passive stretch relationships in human uterine muscle. Am. J. Obstet. Gynecol. 1966, 96, 1055-1059. [CrossRef]

121. Pearsall, G.; Roberts, V. Passive mechanical properties of uterine muscle (myometrium) tested in vitro. J. Biomech. 1978, 11, 167-176. [CrossRef]

122. Kauer, M.; Vuskovic, V.; Dual, J.; Szekely, G.; Bajka, M. Inverse finite element characterization of soft tissues. Med. Image Anal. 2002, 6, 275-287. [CrossRef]

123. Kiss, M.Z.; Hobson, M.A.; Varghese, T.; Harter, J.; Kliewer, M.A.; Hartenbach, E.M.; Zagzebski, J.A. Frequency-dependent complex modulus of the uterus: Preliminary results. Phys. Med. Biol. 2006, 51, 3683-3695. [CrossRef] [PubMed]

124. Omari, E.A.; Varghese, T.; Kliewer, M.A.; Harter, J.; Hartenbach, E.M. Dynamic and quasi-static mechanical testing for characterization of the viscoelastic properties of human uterine tissue. J. Biomech. 2015, 48, 1730-1736. [CrossRef]

125. Giudice, L.C.; Kao, L.C. Endometriosis. Lancet 2004, 364, 1789-1799. [CrossRef] 
126. Altayyeb, A.; Othman, E.; Khashbah, M.; Esmaeel, A.; El-Mokhtar, M.; Lambalk, C.; Mijatovic, V.; Abdelgawad, M. Characterization of mechanical signature of eutopic endometrial stromal cells of endometriosis patients. Reprod. Sci. 2020, 27, 364-374. [CrossRef]

127. Izmailova, L.S.; Vorotelyak, E.A.; Vasiliev, A.V. In vitro modeling of the early development of mouse and human embryos. Russ. J. Dev. Biol. 2020, 51, 271-282. [CrossRef]

128. You, Y.; Stelzl, P.; Zhang, Y.; Porter, J.; Liu, H.; Liao, A.H.; Aldo, P.B.; Mor, G. Novel 3D in vitro models to evaluate trophoblast migration and invasion. Am. J. Reprod. Immunol. 2019, 81, e13076. [CrossRef] [PubMed]

129. Boretto, M.; Cox, B.; Noben, M.; Hendriks, N.; Fassbender, A.; Roose, H.; Amant, F.; Timmerman, D.; Tomassetti, C.; Vanhie, A.; et al. Development of organoids from mouse and human endometrium showing endometrial epithelium physiology and long-term expandability. Development 2017, 144, 1775-1786. [CrossRef]

130. Luddi, A.; Pavone, V.; Semplici, B.; Governini, L.; Criscuoli, M.; Paccagnini, E.; Gentile, M.; Morgante, G.; Leo, V.; Belmonte, G.; et al. Organoids of human endometrium: A powerful in vitro model for the endometrium-embryo cross-talk at the implantation site. Cells 2020, 9, 1121. [CrossRef]

131. Turco, M.Y.; Gardner, L.; Hughes, J.; Cindrova-Davies, T.; Gomez, M.J.; Farrell, L.; Hollinshead, M.; Marsh, S.G.E.; Brosens, J.J.; Critchley, H.O.; et al. Long-term, hormone-responsive organoid cultures of human endometrium in a chemically defined medium. Nat. Cell Biol. 2017, 19, 568-577. [CrossRef]

132. Alzamil, L.; Nikolakopoulou, K.; Turco, M.Y. Organoid systems to study the human female reproductive tract and pregnancy. Cell Death Differ. 2021, 28, 35-51. [CrossRef]

133. Fitzgerald, H.C.; Schust, D.J.; Spencer, T.E. In vitro models of the human endometrium: Evolution and application for women's health. Biol. Reprod. 2021, 104, 282-293. [CrossRef]

134. Psychoyos, A. Uterine receptivity for nidation a. Ann. N. Y. Acad. Sci. 1986, 476, 36-42. [CrossRef]

135. Sharkey, A.M.; Macklon, N.S. The science of implantation emerges blinking into the light. Reprod. Biomed. Online 2013, 27, 453-460. [CrossRef]

136. Singh, H.; Aplin, J.D. Adhesion molecules in endometrial epithelium: Tissue integrity and embryo implantation. J. Anat. 2009, 215, 3-13. [CrossRef] [PubMed]

137. Kim, S.M.; Kim, J.S. A review of mechanisms of implantation. Dev. Reprod. 2017, 21, 351-359. [CrossRef] [PubMed]

138. Moore, S.W.; Roca-Cusachs, P.; Sheetz, M.P. Stretchy proteins on stretchy substrates: The important elements of integrin-mediated rigidity sensing. Dev. Cell 2010, 19, 194-206. [CrossRef] [PubMed]

139. Orr, A.W.; Helmke, B.P.; Blackman, B.R.; Schwartz, M.A. Mechanisms of mechanotransduction. Dev. Cell 2006, 10, 11-20. [CrossRef]

140. Farquhar, M.G.; Palade, G.E. Junctional complexes in various epithelia. J. Cell Biol. 1963, 17, 375-412. [CrossRef] [PubMed]

141. Unal, M.; Alapan, Y.; Jia, H.; Varga, A.G.; Angelino, K.; Aslan, M.; Sayin, I.; Han, C.; Jiang, Y.; Zhang, Z.; et al. Micro and nano-scale technologies for cell mechanics. Nanobiomedicine 2014, 1, 5. [CrossRef]

142. Eyckmans, J.; Boudou, T.; Yu, X.; Chen, C.S. A hitchhiker's guide to mechanobiology. Dev. Cell 2011, 21, 35-47. [CrossRef] [PubMed]

143. Thorne, J.T.; Segal, T.R.; Chang, S.; Jorge, S.; Segars, J.H.; Leppert, P.C. Dynamic reciprocity between cells and their microenvironment in reproduction. Biol. Reprod. 2015, 92, 25. [CrossRef] [PubMed]

144. Molnar, K.; Labouesse, M. The plastic cell: Mechanical deformation of cells and tissues. Open Biol. 2021, 11, 210006. [CrossRef]

145. Xie, Y.; Cui, D.; Sui, L.; Xu, Y.; Zhang, N.; Ma, Y.; Li, Y.; Kong, Y. Induction of forkhead box M $_{1}\left(\right.$ FoxM $\left._{1}\right)$ by EGF through ERK signaling pathway promotes trophoblast cell invasion. Cell Tissue Res. 2015, 362, 421-430. [CrossRef] [PubMed]

146. Boyd, N.F.; Li, Q.; Melnichouk, O.; Huszti, E.; Martin, L.J.; Gunasekara, A.; Mawdsley, G.; Yaffe, M.J.; Minkin, S. Evidence that breast tissue stiffness is associated with risk of breast cancer. PLoS ONE 2014, 9, e100937. [CrossRef] [PubMed]

147. Upagupta, C.; Shimbori, C.; Alsilmi, R.; Kolb, M. Matrix abnormalities in pulmonary fibrosis. Eur. Respir. Rev. 2018, $27,180033$. [CrossRef] [PubMed] 